Mess Eleonora, Rybakiewicz Alice, Pawelak Agnieszka, Lisowska Aleksandra, Ornat Maciej. Assessment of the level of anxiety of caring for disabled. Journal of Education, Health and Sport. 2019;9(2):165-182. eISNN 2391-8306. DOI http://dx.doi.org/10.5281/zenodo.2561188

http://ojs.ukw.edu.pl/index.php/johs/article/view/6573

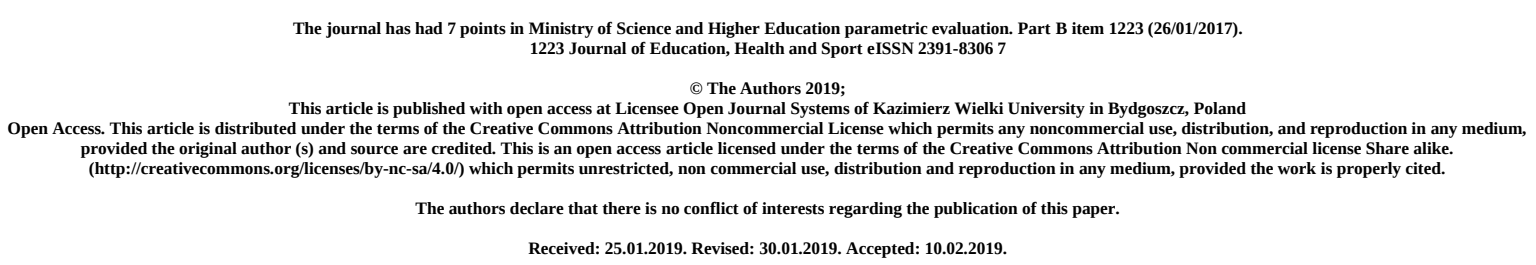

\title{
Assessment of the level of anxiety of caring for disabled
}

\section{Eleonora Mess 1, Alice Rybakiewicz 2, Agnieszka Pawelak 3,4, Aleksandra Lisowska 1,} Maciej Ornat 3,4

${ }^{1.2}$ Department of Oncology and Palliative Care at the Medical University in Wroclaw, Head Prof. Tomasz Szydełko.

3 Student Scientific Association for Health Promotion and Disease Prevention at the Department of Geriatrics Clinic and the Medical University of Wroclaw.

Dr. Iwona Pirogowicz.

${ }^{4}$ Department of Human Morphology and Embryology, Department of Histology and Embryology, Medical University in Wroclaw.

Head: P. Dzięgiel

Address for correspondence Dr n. med. Eleonora Mess, Department of Oncology and Palliative Care, Department of Clinical Nursing, Faculty of Earth Sciences, Medical University of Wroclaw, ul. K. Bartla 5, 51-618 Wroclaw tel. 71/7841843, e-mail:eleonora.mess@umed.wroc.pl 


\section{Abstract}

Admission: Care for disabled child may present many difficulties and cause stressful situations that generate negative emotions. One of them is fear.

Objective of the work: Assessment of the level of anxiety state and trait in people taking care of a disabled child.

Materials and methods: The study was conducted among 100 employees center for disabled children and Wierzbice in Katy Wroclawskie. The research tool was the Inventory and the State Trait Anxiety (STAI).

Results: The level of anxiety carers of people with disabilities depends on the age of the subjects $(p=0.025)$, professional experience $(p=0.047)$, operating system $(0.002)$ and the degree of disability of children $(\mathrm{p}=0.004)$. While the intensity of the drug is not affected by gender, education and occupation.

Results: The level of anxiety careers of people with disabilities depends on the age of the subjects $(p=0.025)$, professional experience $(p=0.047)$, operating system $(0.002)$ and the degree of disability of children $(\mathrm{p}=0.004)$. While the intensity of the drug is not affected by gender, education and occupation.

Discussion: Both the age and experience of the work associated with sophistication and getting used to disability beneficiaries. The impact may also have a stable position in the life of the elderly. The importance of the degree of disability is unmistakable, taking into account both the physical stress and emotional caregivers.

Key words: Anxiety, care, children with disabilities

\section{Admission}

Anxiety is one of the emotional experiences, accompanying every person throughout life. Performing with the development processes appears in the form of a response to various threats [1]. This is the general feeling of uncertainty about the indefinite presenting a risk of the stimulus. While fear is a natural phenomenon, occurring as a simple reaction to danger. In 
contrast to fear the cause can be clearly specify [2].

Anxiety can take the form of undefined anxiety as well as anxiety attacks, occurring in certain situations in the form of somatic symptoms. Anxiety reactions when they lose their adaptive function and become inadequate to stimuli. Anxiety create circumstances that do not have overt signs of danger. [3] The reduction or removal of feelings of anxiety leads to the disappearance of the symptoms of the described [4]. In the literature there is a breakdown experience anxiety genetically four groups of anxiety. These are: biological anxiety, social anxiety, anxiety, fear and moral disintegration. All of these, according to him can be reduced to the basic fear, the fear of death, because death as the ultimate threat to every living creature triggers the alarm signal [4]. Among nurses in contact with people dying, that fear has a major impact on the quality of services provided. Exposure to the patient's death makes them more aware of their mortality [5].

Research indicates anxiety, aggression and depression as emotional states psychopathological picture of a color negative are often suppressed by people with a high degree of socialization. In a community such as carers of people with disabilities arises therefore the problem of accumulation of the above emotions.

Stress genic certain professions is a frequent topic of discussion and research [6]. There are two dimensions of the load training: subjective and objective. To load an objective, include: physical effort and time. On the other hand, it refers to the subjective experience and attitudes related to the exercise of care [7]. The group of professions, performing the particularly difficult and burdensome profession are $\mathrm{m}$. In. nurse. This requires willingness from them to contact people suffering, responsibility for their health and lives and while performing their professional duties in shifts, negatively affecting the physical and mental health. All this means that the profession of nurses working as a generator of high intensity stress [6]. Similar features have also other professionals, such as medical caregivers, therapists, nurses, doctors, speech therapists, psychologists, occupational therapists, educators, teachers, and even the orderlies [8]. Any person having the care of a disabled child creates the so-called. a team of professionals ready to respond in any threatening situation.

According to the WHO defines a disabled person who cannot partially or completely lead independent individual and social life, as a result of congenital or acquired impairment of physical and / or mental [9]. 
Diagnosing the degree of deviation from the norm, especially in the field of intellectual functioning and social adaptation was the traditional base for defining disability. Such a theory convinces us that intellectual disability is not a disease and the effect of various pathogens, in effect giving the state of irreversible [10].

Significantly lower than the average general intellectual functioning level is a level whose value is lower than two standard deviations from the mean. The upper limit of the developmental age is considered the age of 18 years. To fully diagnose mental retardation does not consider only the low IQ, but also adaptive behavior. They are understood as the efficiency or extent to which the requirements are carried out independent of personal and social responsibility of the entity which is expected from the particular age and environment [11].

In summary factors related to the working environment may imply the occurrence of depression and raise the level of anxiety and depression [6].

\section{Materials and methods}

The aim of the study is to analyze the level of anxiety in people taking care of the disabled. The study involved 100 caregivers who are employees of two centers for children with disabilities in the village and Wierzbice Special School - Educational in Katy Wroclawskie.

Respondents were divided into groups according to age: 20-35 years, 36-45 years and 46-60 years. In the first and second age bracket is the number of respondents for each 30 people, in the third - 40 people. In both centers, dominated by female. They studied 84 women and 16 men.

Individuals differ in the system work. Nurses and medical careers have a system working 12-hour clock. Occupations type: physiotherapist / Rehabilitation therapist, orderlies, occupational therapists and speech therapists working in the system of 8 hours from Monday to Friday. While teachers and educators working in the "card teacher." The survey also distinguished educators unfractionated whose system of work may include non-working days and hours of the evening or night.

The SOW-e and sol-u is a total of 65 charges, were divided in 5 groups depending on the degree of disability. There is a group ORW (Center for Educational-rehabilitation), it is a group of severely retarded children, where are the boys and girls. Most of the children in this 
group, in addition to a deep degree of mental retardation, also has a significant dysfunction in terms of motor skills. In all groups there is a very large discrepancy age. In both plants provided 24-hour care. A different situation exists in the Special Training and Education Center in Katy Wroclawskie, where there are children and young people with mental disabilities in the mild and moderate. There exists a small percentage of children with physical disabilities.

The size of the research group, depending on the care of children with varying degrees of disability.

\begin{tabular}{|l|c|c|}
\hline The degree of disability of children & $\begin{array}{c}\text { The number of people } \\
\text { taking care }\end{array}$ & $\begin{array}{c}\text { Percentag } \\
\text { e }\end{array}$ \\
\hline + standard physical disability & 5 & $5 \%$ \\
\hline light and light coupled with the movement & 18 & $18 \%$ \\
\hline moderate and moderate coupled with the movement & 19 & $19 \%$ \\
\hline $\begin{array}{l}\text { significant and substantial coupled with the } \\
\text { movement }\end{array}$ & 8 & $8 \%$ \\
\hline deep and profound coupled with the movement & 12 & $12 \%$ \\
\hline $\begin{array}{l}\text { Mixed groups - with all degrees of mental retardation } \\
\text { and children coupled with the movement of the } \\
\text { children except for deep }\end{array}$ & 28 & $28 \%$ \\
\hline all kinds of disabilities, including deep & 10 & $10 \%$ \\
\hline Altogether & 100 & $100 \%$ \\
\hline
\end{tabular}

Research at the Center in Wierzbice were conducted in November and December 2014, while in Katy Wroclawskie were implemented in April 2015.

The anxiety in people taking care of the disabled were examined using Inventory and the State Trait Anxiety (Wrześniewski K. and T. Sosnowski). Adopted criterion for the distribution of severity of anxiety into five classes according to Spielberger: 0-20 points - fear very low; 21-40 points - low anxiety; 41-60 points - the average anxiety; 61-80 points - a drug high; 81-100 points - very high anxiety.

In the first X-1 scale the theorem on the subjective feelings of the individual. Tested by choosing one answer addresses the current state or to his mental state at the time of completion of the test.

However, in a sheet of $\mathrm{X}-2$ categorization response refers to the frequency of occurrence of data in a test felt. 


\section{Results}

Anxiety as a state in people taking care of the disabled is eligible low ranges of anxiety (51\%) and medium (49\%). In contrast, anxiety as measured characteristic to a minor extent in anxiety scale very low (only 1\%) and low intervals of anxiety (53\%) and mid (46\%).

No statistically significant difference in anxiety between men and women $(\mathrm{p}=0.262)$. The intensity of anxiety in both subgroups occur at low and medium. In women greater fear prevails low (56\%) above the average (44\%), while in men the percentage was determined higher values for the mean of anxiety (75\%).

In the study group analyzed 30 people aged 20 to 35 years, 30 people aged from 36 to 45 years, and 40 of the next range of 46 to 60 years. The intensity of anxiety depending on the age of the respondents is at the low and medium. The general trend is a decrease in the level of anxiety with an increasing age of respondents. In the youngest age group, the average level of anxiety is higher by $30 \%$ than other groups, and the low intensity of the anxiety is about $30 \%$ lower than in older patients.

The intensity anxiety- state after differentiation on age.

\begin{tabular}{|l|l|l|l|l|l|}
\hline \multicolumn{2}{|c|}{ Anxiety as a state } & \multicolumn{2}{|l|}{ Age } & \multirow{2}{*}{ altogether } \\
\cline { 3 - 6 } & & $\begin{array}{l}20-35 \\
\text { years }\end{array}$ & $\begin{array}{l}\text { 36-45 } \\
\text { years }\end{array}$ & $\begin{array}{l}46-60 \\
\text { years }\end{array}$ & \\
\hline \multirow{2}{*}{ short } & Population & 9 & 18 & 24 & 51 \\
\cline { 2 - 7 } & Percentage & thirty\% & $60 \%$ & $60 \%$ & $51 \%$ \\
\hline \multirow{2}{*}{ average } & Population & 21 & 12 & 16 & 49 \\
\cline { 2 - 7 } & Percentage & $70 \%$ & $40 \%$ & $40.0 \%$ & $49 \%$ \\
\hline \multirow{2}{*}{$\begin{array}{l}\text { altogethe } \\
\text { r }\end{array}$} & Population & thirty & thirty & 40 & 100 \\
\cline { 2 - 7 } & Percentage & $100 \%$ & $100 \%$ & $100 \%$ & $100 \%$ \\
\hline
\end{tabular}

Using ANOVA test, we can conclude that there are statistically significant differences in state anxiety among people of different age $(\mathrm{p}=0.025)$. The most diverse group range is 36-45. Only in this group apart from the levels: low and medium levels of anxiety also showed very low. 
Descriptive statistics depending on the age of the respondents.

\begin{tabular}{|l|l|l|l|}
\hline descriptive statistics & $\begin{array}{l}\mathbf{2 0}-\mathbf{3 5} \\
\text { years }\end{array}$ & $\begin{array}{l}\mathbf{3 6}-\mathbf{4 5} \\
\text { years }\end{array}$ & $\mathbf{4 6}-\mathbf{6 0}$ years \\
\hline Average & 43.43 & 39.90 & 38.33 \\
\hline Standard deviation & 6.71 & 9.17 & 7.19 \\
\hline
\end{tabular}

Statistical analysis showed that the level of anxiety in the age group 46-60 years is significantly lower compared to the 20-35-year age group (Tukey's test, $\mathrm{p}<0.05$ ).

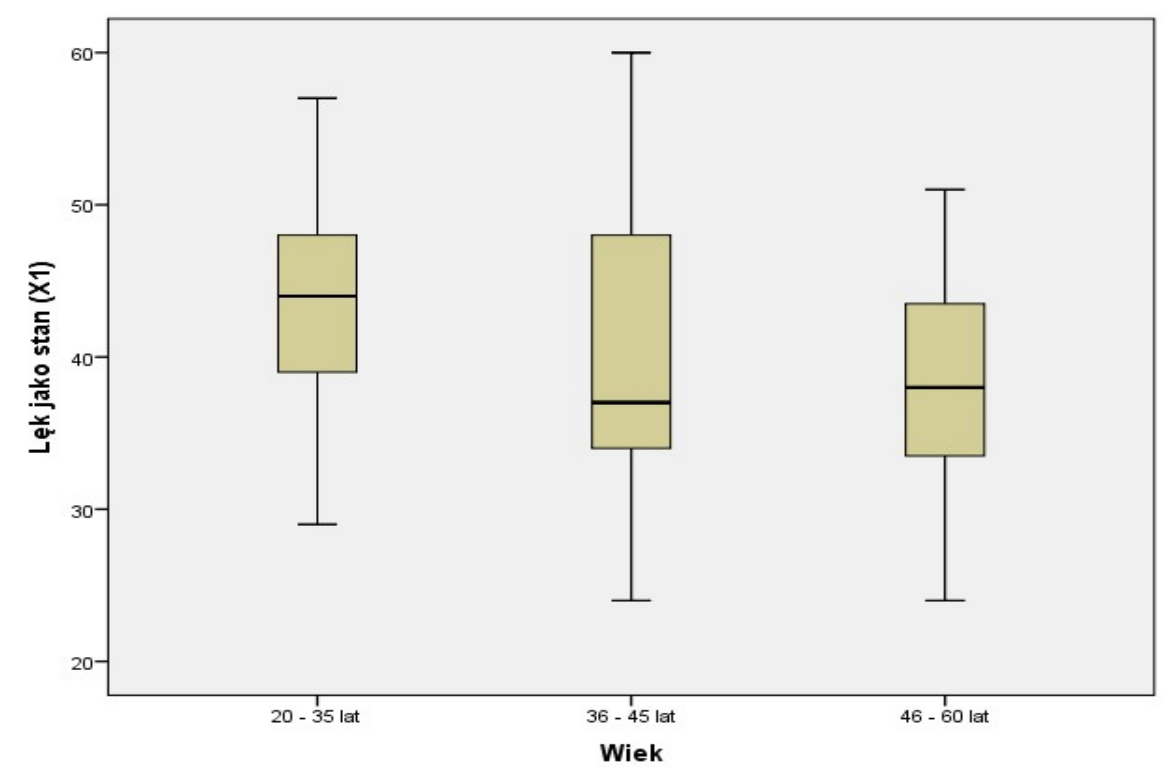

State anxiety scores $(\mathrm{X}-1)$, the median and the standard deviation depending on the age.

Flow of the drug - treated groups prior to the average higher education and is at low level and the medium. Both groups received the results of a percentage very close to each other. We conclude that there are no statistically significant differences in these variables and education does not affect the level of anxiety among caregivers of people with disabilities ( $\mathrm{p}=$ 0.168). The intensity of anxiety in the range of properties depending on the educational level is at a very low (1\%), low (53\%) and middle (46\%). In all patients in the group with primary low, the level of anxiety, and in $100 \%$ in the group with vocational - intermediate level. The intensity of the fear in the other two groups are close to each other, close to half of those with secondary education (50\%) and higher education (52.8\%) showed a low level of anxiety. 


\begin{tabular}{|l|l|l|l|l|l|l|}
\hline \multicolumn{2}{|l}{ Anxiety as a state } & \multicolumn{3}{ll}{ Education } & \multicolumn{2}{l|}{ altogether } \\
\cline { 3 - 7 } & basic & $\begin{array}{l}\text { professio } \\
\text { nal }\end{array}$ & average & higher & \\
\hline Short & $\begin{array}{l}\text { Populati } \\
\text { on }\end{array}$ & 3 & 1 & 11 & 36 & 51 \\
\hline $\begin{array}{l}\text { Percenta } \\
\text { ge }\end{array}$ & $100 \%$ & $100 \%$ & $45.8 \%$ & $50 \%$ & $51 \%$ \\
\hline average & $\begin{array}{l}\text { Populati } \\
\text { on }\end{array}$ & 0 & 0 & 13 & 36 & 49 \\
\hline $\begin{array}{l}\text { Percenta } \\
\text { ge }\end{array}$ & $0 \%$ & $0 \%$ & $54.2 \%$ & $50 \%$ & $49 \%$ \\
\hline altogether & $\begin{array}{l}\text { Populati } \\
\text { on }\end{array}$ & 3 & 1 & 24 & 72 & 100 \\
\hline $\begin{array}{l}\text { Percenta } \\
\text { ge }\end{array}$ & $100 \%$ & $100 \%$ & $100 \%$ & $100 \%$ & $100 \%$ \\
\hline
\end{tabular}

The intensity anxiety- state after differentiation of education of the respondents.

Group respondents were also analyzed for correlation with the level of the profession performed anxiety. The results show that the lowest level of anxiety-holders feel the competition from the group of "other". In this subgroup observe a significant advantage anxiety low (80\%) above the average (20\%). A similar level of anxiety occurs in nurses and medical careers. The advantage of anxiety over medium low, we see a group of educators / teachers, and educators in the Help Group. The latter profession presents the highest levels of anxiety in relation to other groups which has a significant percentage advantage anxiety average (75\%) of the low (25\%). No statistically significant differences in state anxiety in people engaged in various professions (Tukey test: $\mathrm{p}=0.03$ ). 


\begin{tabular}{|c|c|c|c|c|c|c|c|}
\hline \multicolumn{2}{|c|}{ Anxiety as a state } & \multicolumn{5}{|c|}{ Profession } & \multirow[t]{2}{*}{ altogether } \\
\hline & & nurse & $\begin{array}{l}\text { medical } \\
\text { carer }\end{array}$ & tutor / teacher & help educators & $\begin{array}{l}\text { "Other- } \\
\text { therapists, } \\
\text { orderlies, } \\
\text { speech } \\
\text { therapist, } \\
\text { occupationa } \\
\text { l therapy }\end{array}$ & \\
\hline \multirow{2}{*}{ short } & $\begin{array}{l}\text { Populat } \\
\text { ion }\end{array}$ & 7 & 9 & 25 & 2 & 8 & 51 \\
\hline & $\begin{array}{l}\text { Percent } \\
\text { age }\end{array}$ & $70 \%$ & $60 \%$ & $43.9 \%$ & $25 \%$ & $80 \%$ & $51 \%$ \\
\hline \multirow{2}{*}{ average } & $\begin{array}{l}\text { Populat } \\
\text { ion }\end{array}$ & 3 & 6 & 32 & 6 & 2 & 49 \\
\hline & $\begin{array}{l}\text { Percent } \\
\text { age }\end{array}$ & thirty\% & $40 \%$ & $56.1 \%$ & $75 \%$ & $20 \%$ & $49 \%$ \\
\hline \multirow{2}{*}{ altogether } & $\begin{array}{l}\text { Populat } \\
\text { ion }\end{array}$ & 10 & 15 & 57 & 8 & 10 & 100 \\
\hline & $\begin{array}{l}\text { Percent } \\
\text { age }\end{array}$ & $100 \%$ & $100 \%$ & $100 \%$ & $100 \%$ & $100 \%$ & $100 \%$ \\
\hline
\end{tabular}

The intensity of the differentiation status anxiety- profession studied.

Given trait anxiety, anxiety levels create a very low level, low and mid. The same intensity of fear is characterized by a group of nurses and people in positions of "other" (the level of trait anxiety is low: 70\%, the level of the average: $30 \%)$. In contrast to the anxiety as a state, a sub-group of practitioners to help educators, characterized by anxiety as a feature low (62.5\%) as an advantage over drug intensity average (37.5\%). No statistically significant difference in trait anxiety among employees' centers performing other professions (ANOVA: $\mathrm{p}=0.801)$. 


\begin{tabular}{|c|c|c|c|c|c|c|c|}
\hline \multicolumn{2}{|c|}{ As a feature of Anxiety } & \multicolumn{5}{|c|}{ Profession } & \multirow[t]{2}{*}{ altogether } \\
\hline & & Nurse & $\begin{array}{l}\text { medical } \\
\text { carer }\end{array}$ & tutor / teacher & help educators & $\begin{array}{l}\text { other-therapists, } \\
\text { orderlies, speech } \\
\text { therapist, } \\
\text { occupational } \\
\text { therapy }\end{array}$ & \\
\hline \multirow[t]{2}{*}{ very low } & Population & 0 & 0 & 1 & 0 & 0 & 1 \\
\hline & Percentage & - & - & $1.8 \%$ & - & - & $1.0 \%$ \\
\hline \multirow[t]{2}{*}{ short } & Population & 7 & 7 & 27 & 5 & 7 & 53 \\
\hline & Percentage & $70 \%$ & $46.7 \%$ & $47.4 \%$ & $62.5 \%$ & $70 \%$ & $53 \%$ \\
\hline \multirow[t]{2}{*}{ average } & Population & 3 & 8 & 29 & 3 & 3 & 46 \\
\hline & Percentage & thirty\% & $53.3 \%$ & $50.9 \%$ & $37.5 \%$ & thirty\% & $46 \%$ \\
\hline \multirow[t]{2}{*}{ altogether } & Population & 10 & 15 & 57 & 8 & 10 & 100 \\
\hline & Percentage & $100 \%$ & $100 \%$ & $100 \%$ & $100 \%$ & $100 \%$ & $100 \%$ \\
\hline
\end{tabular}

Anxiety- intensity characteristics of the diversity of the profession of respondents.

Also analyzed the level of state anxiety in people dealing with children with disabilities, depending on experience. The subgroup with the highest level of anxiety low (66.7\%) are people who have been working from 5 to 15 years. The other two subgroups prevalent anxiety average (61.5\% for up to 5 years and $54.5 \%$ for patients over 15 years). This means that seniority affects the level of state anxiety. It has been shown statistically significant between different groups of $0-5$ years and 5 - 15 years (Tukey test: $\mathrm{p}=0.042$ ).

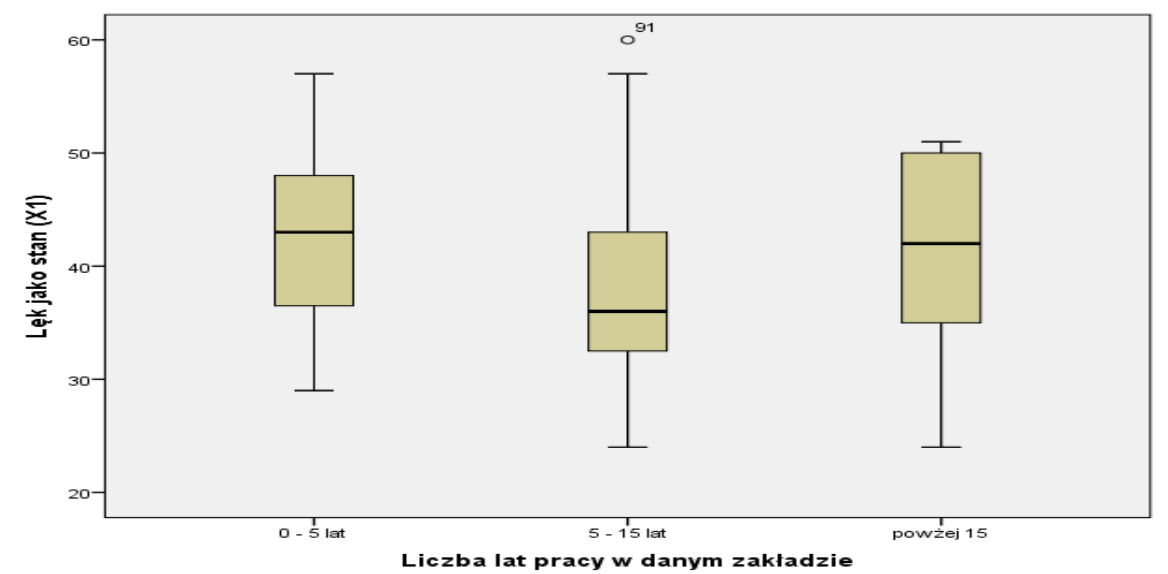

State anxiety scores (X-1), the median and the standard deviation depending on the length of service. 
We are seeing similar results - anxiety characteristics depending on the number of years of working people taking care of the disabled in the establishments. The lowest level of anxiety reached a subgroup representing individuals who have worked for a plant from 5 to 15 years. $2.6 \%$ of people rate their anxiety on a very low level, while $64.1 \%$ at low level. While the highest, the average level of anxiety - trait occurs in the group with the oldest work experience (54.5\%).

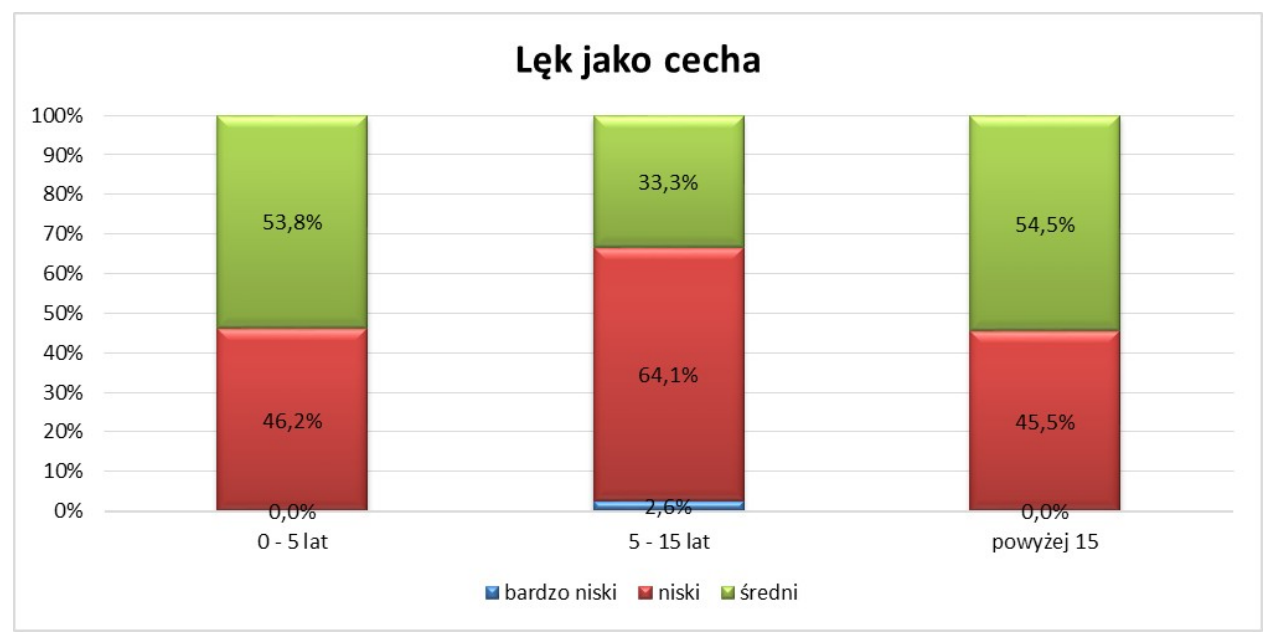

ANXEITY- level of differentiation characteristics of the number of years studied in the plant.

Research group analyzed depending on the operating system of caring for disabled people in the resort. When a state of anxiety, anxiety reached the lowest level group of teachers unfractionated working on the web, in which prevails a low level of fear (66.7\%) on the average (33.3\%). Fared quite differently fractionated group of teachers working at the school, the average level of anxiety prevails (62.2\%) of the low (37.8\%). The systems work with both 12-hour and 8-hour prevailing low level of anxiety. However, the higher value is achieved in the group of working after 12 hours. There was no significant correlation, however, between the operating system and the level of state anxiety (level of significance 0.043).

In all subgroups examined, due to the system of work, prevailing low-level anxietyfeatures, aside from fractionated group of teachers at the school. It is in this group reaches a higher average level of anxiety (57.8\%). There were statistically significant the differences in anxiety as a feature in relation to the working system: between groups "tab of the teacher unfractionated web" and "card fractionated school teacher '(Tukey test: $\mathrm{p}=0.001$ ). 


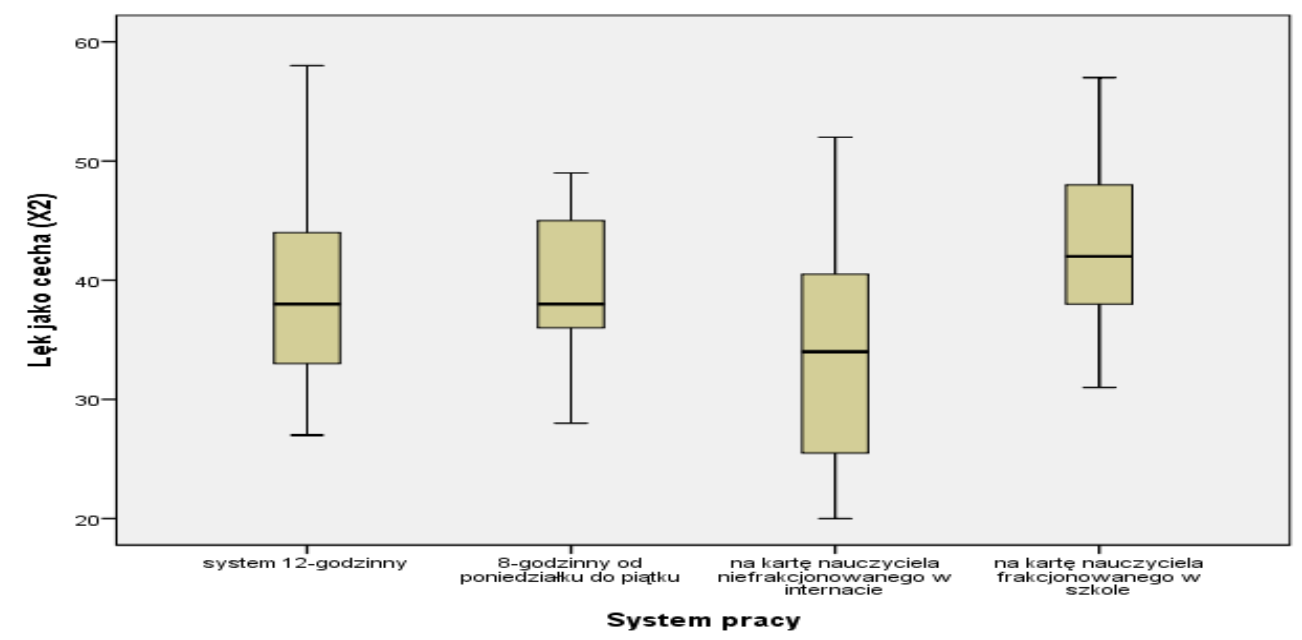

Trait anxiety scores (X-2), the median and the standard deviation depending on the system operation.

The research group formed 7 subgroups based on the degree of disability of children, over which employees exercise care centers.

The intensity anxiety- state after differentiation degree of impairment of children, which deal with subjects.

\begin{tabular}{|c|c|c|c|c|c|c|c|c|c|}
\hline \multirow{2}{*}{\multicolumn{2}{|c|}{ Anxiety as a state }} & \multicolumn{7}{|c|}{ The degree of disability of the child } & \multirow[t]{2}{*}{ altogether } \\
\hline & & 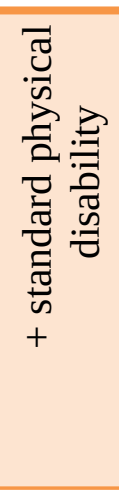 & 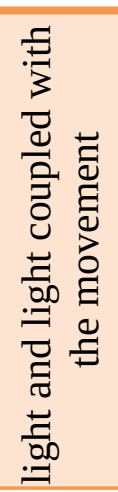 & 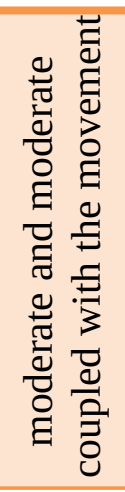 & 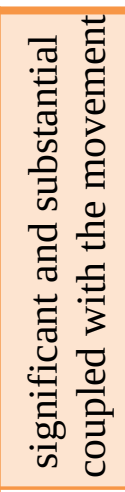 & 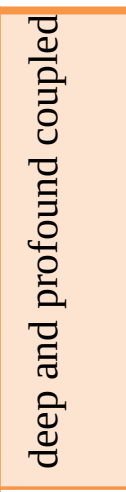 & 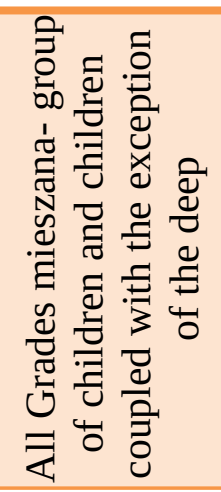 & 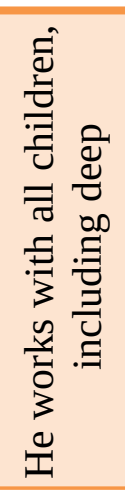 & \\
\hline \multirow[t]{2}{*}{ Short } & Population & 2 & 9 & 5 & 2 & 6 & 21 & 6 & 51 \\
\hline & Percentage & $40 \%$ & $50 \%$ & $26 \%$ & $25 \%$ & $50 \%$ & $75 \%$ & $60 \%$ & $51 \%$ \\
\hline \multirow[t]{2}{*}{ average } & Population & 3 & 9 & 14 & 6 & 6 & 7 & 4 & 49 \\
\hline & Percentage & $60 \%$ & $50 \%$ & $73.7 \%$ & $75 \%$ & $50 \%$ & $25 \%$ & $40 \%$ & $49 \%$ \\
\hline \multirow[t]{2}{*}{ Altogether } & Population & 5 & 18 & 19 & 8 & 12 & 28 & 10 & 100 \\
\hline & Percentage & $100 \%$ & $100 \%$ & $100 \%$ & $100 \%$ & $100 \%$ & $100 \%$ & $100 \%$ & $100 \%$ \\
\hline
\end{tabular}

The highest level of anxiety (medium intensity) present people dealing with children with severe and moderate disability (respectively $73.7 \%$ and $75 \%$ ). Another group, which is 
dominated by fear at the average (60\%) of the low (40\%) are people dealing with physically disabled children with mental norm.

The highest average value of the intensity of fear we see a group of guardians mentally healthy children (up to 80\%), followed by groups of employees caring for children moderately (31.6\%) and significantly handicapped (37.5\%). In the remaining groups prevails anxiety levels low. The highest value is achieved in the group of caring for children with mental and physical disabilities deep.

Anxiety- intensity characteristics of the differentiation degree of impairment of children, which deal with subjects.

\begin{tabular}{|c|c|c|c|c|c|c|c|c|c|}
\hline \multicolumn{2}{|c|}{ As a feature of Anxiety } & \multicolumn{7}{|c|}{ The degree of disability of the child } & \multirow[t]{2}{*}{ altogether } \\
\hline & & 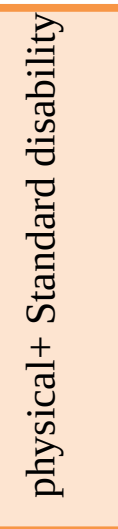 & 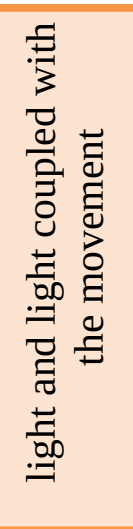 & 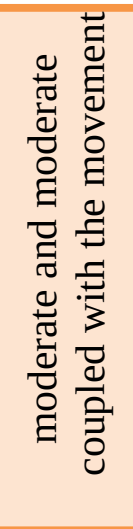 & 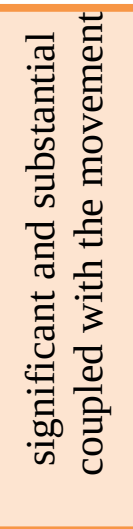 & 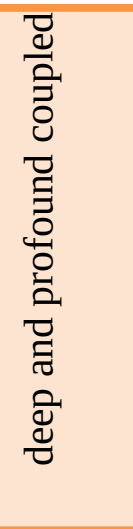 & 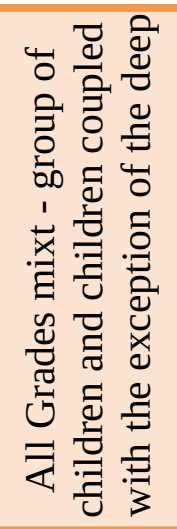 & 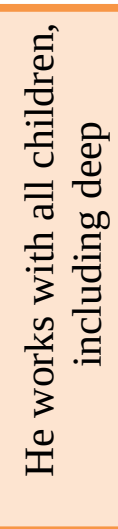 & \\
\hline \multirow[t]{2}{*}{ very low } & Population & 0 & 0 & 0 & 0 & 0 & 1 & 0 & 1 \\
\hline & Percentage & - & - & - & - & - & $3.6 \%$ & - & $1 \%$ \\
\hline \multirow[t]{2}{*}{ short } & Population & 1 & 11 & 6 & 3 & 8 & 18 & 6 & 53 \\
\hline & Percentage & $20 \%$ & $61.1 \%$ & $31.6 \%$ & $37.5 \%$ & $66.7 \%$ & $64.3 \%$ & $60 \%$ & $53 \%$ \\
\hline \multirow[t]{2}{*}{ average } & Population & 4 & 7 & 13 & 5 & 4 & 9 & 4 & 46 \\
\hline & Percentage & $80 \%$ & $38.9 \%$ & $68.4 \%$ & $62.5 \%$ & $33.3 \%$ & $32.1 \%$ & $40 \%$ & $46 \%$ \\
\hline \multirow[t]{2}{*}{ altogether } & Population & 5 & 18 & 19 & 8 & 12 & 28 & 10 & 100 \\
\hline & Percentage & $100 \%$ & $100 \%$ & $100 \%$ & $100 \%$ & $100 \%$ & $100 \%$ & $100 \%$ & $100 \%$ \\
\hline
\end{tabular}

It was confirmed difference in state anxiety among caregivers of children with varying degrees of disability. A statistically significant correlation exists between "moderate and coupled with the movement group" and "mixed - all grades and children coupled except for children deep" ( $\mathrm{p}=0.039$ ) and between "a substantial and significant coupled with the movement group" and "Mixed - all degrees and children coupled except for children deep "(p $=0.023)$. 


\section{Discussion}

The level of anxiety as state employees in the surveyed centers for disabled children, which they care depends on the age of the respondents, seniority and level of disability children. The results indicate that the higher the age of the people caring for the disabled, the lower the level of anxiety. This is most likely the result of the fact that the age of the respondents is associated with experience at work, manifesting a greater sophistication in relation to disability. Similar results were obtained in a work Desley Hegne G. et al., Paying attention to the relationship experience younger age groups and lower levels of education of anxiety [12]. The analysis confirms that workers with the shortest number of years of work (from 0 to 5 ) experience greater anxiety than those working longer (5 to 15 years). Anxiety level rises again at those working the longest (over 15 years). Professional experience as a reducing agent anxiety was also confirmed by Nicolas Oyana MF et al. [13]. The effect of these results appears to be related to the cycle of biological activity and social subjects. Younger workers are at an early stage of working life, private and family assume prepare for officiating roles in the family (wife the role of mother, husband or father). Older respondents have usually already stabilized the situation, both professional and personal, yet are still in a period of full biological activity and social. While the oldest respondents, approaching the retirement stage, often experiencing mental and physical discomfort due to lower activity, gradually deteriorating health and menopause in women. There is no loss of impact strength by increasing with age as accompanying the aging process [14]. To the said situation, there is an additional factor. which confirms the results obtained, it is namely the transformation in Poland, namely employment policy and the feeling gradually declining standard of living. The consequences of change, of a color negative affect all workers, but it seems that the threat of unemployment is greatest in those with the shortest and longest number of years of work. This is confirmed by a survey of 2004 nurses working in hospitals, clinics, hospices and nursing homes public, who studied levels of anxiety, depression and aggression. [6 that the threat of unemployment is greatest in those with the shortest and longest number of years of work. This is confirmed by a survey of 2004 nurses working in hospitals, clinics, hospices and nursing homes public, who studied levels of anxiety, depression and aggression. [6 that the threat of unemployment is greatest in those with the shortest and longest number of years of work. This is confirmed by a survey of 2004 nurses working in hospitals, clinics, hospices and nursing homes public, who studied levels of anxiety, depression and aggression [6]. 
The highest intensity of fear is in the group of people taking care of children with significant impairment coupled with him. Chronic disease, in particular, runs with a disability restricts the functioning of affected not only her child but also his guardians [6]. In the childcare with physical further need is greater expenditure of physical force [14]. Along with the improvement of both functional and neurological ward, reduces the intensity of emotional exhaustion protector [15]. Therefore, based on the obtained results the heavier the child's condition, the greater the burden of care.

The level of fear is dependent on the operating system of the respondents. Definitely less anxiety characterized by unfractionated teachers. Perhaps this is conditioned by different social environment, which demonstrates how literature affects the level of anxiety or caregiver burden. [6] According to many studies in the system of shift work 8 or 12 hours is a factor further deepening feeling of anxiety and depression among nurses [13] [16]. This involves disturbed the rhythm of the day, reduced sleep quality and, consequently fatigue. Sevim Çelik et al. have shown that this factor exhibits the strongest correlation with the level of anxiety in the nurses could lead to a burnout syndrome and other psychiatric disorders [17] [18].

A statistically significant level of anxiety is not affected by gender, occupation and education. Similar results were obtained by Dave D et all, the study stress levels and depression in caregivers of people with disabilities, where no correlation was found gender guardians of the intensity of the studied traits [19] In terms of gender guardians biggest differences are described in connection with the negative effects of shift work, which women seem to be more sensitive and more susceptible to the adverse effects [13]. The structure of the research group is a limitation of our work, does not allow for an objective assessment of the impact of gender on test feature. The comparative analysis should be carried out because on an adequate number of respondents with a lack of domination of women over men. According to most scientific literature, caregivers of people with chronic diseases are mostly women. [8, 14, 15, 20, 21, 22] Additionally, according to Desley Hegne G. et al. important factor in the emotional state seems to be the guardians of education, affecting not only the level of anxiety but also on the mood and willingness to undertake further training. [12] No correlation with education level of anxiety in the test in our work is probably related to the very low number of respondents with secondary, vocational and prevalent among caregiver's higher education. 


\section{Summary}

The level of state anxiety among patients, careers of disabled children, occurs at low and medium. Anxiety as a state depends on factors such as seniority, degree of disability of children and the age of the respondents. The level of trait anxiety (behavioral permanent disposal) affects: center location, type of facility, and the system working careers of people with disabilities. There was no correlation with sex education and intensity of anxiety in patients.

\section{Bibliography}

[1] Tłokiński W.: Lęk, zjawisko umotywowane. Wyd. Uniwersytetu Gdańskiego, Warszawa 1995.

[2] Solecka G.: Lęk tanatyczny., Zakład Medycznych Nauk Społecznych, Akademia Medyczna im. Piastów Śląskich we Wrocławiu, Piel. Zdr. Publ. 2011, 1, 3, 251-257.

[3] National Institute of Mental Health 3 września 2008.

[4] Kępiński A.: Lęk. Wyd. Literackie, Kraków 2012.

[5] Peters L., et al. How death anxiety impacts nurses' caring for patients at the end of life: a review of literature. The open nursing journal, 2013, 7: 14.

[6] Kliszcz J., Nowicka-Sauer K., Sadowska A., Trzeciak B.: Poziom lęku, depresji i agresji u pielęgniarek, a ich satysfakcja z życia i z pracy zawodowej. W: Medycyna Pracy 2004, 55 (6).

[7] Grabowska-Fudala B., Jaracz K.: Obciq̨żenie osób sprawujq̨cych opiekę nad chorymi po udarze mózgu- wyniki wstępne. W: Udar mózgu 2007, tom 9, nr 1.

[8] Bednarek A., Bryczek M.: Trudności w realizacji opieki nad dziećmi z mózgowym porażeniem dziecięcym. W: Medycyna Ogólna i Nauki o Zdrowiu., Tom 18, Nr4, Lublin 2012.

[9] Bilski D., Wilmowska-Pietruszyńska A.: Międzynarodowa Klasyfikacja Funkcjonowania, Niepełnosprawności i Zdrowia. Niepełnosprawność- zagadnienia, problemy, rozwiązania $\mathrm{Nr}$ II/2013(7). 
[10] Matuszak K.: Pozytywne mierniki zdrowia u uczniów z upośledzeniem umysłowym. Rozprawa doktorska. Poznań 2014.

[11] Smoleń R.: Poczucie jakości życia u młodzieży z upośledzeniem umysłowym. Zeszyty Naukowe Małopolskiej Wyższej Szkoły Ekonomicznej w Tarnowie, T. 18, Nr.1/2011.

[12] Hegney Desley G., et al. Compassion satisfaction, compassion fatigue, anxiety, depression and stress in registered nurses in Australia: study 1 results. Journal of Nursing Management, 2014, 22.4: 506-518.

[13] Øyane N. MF, et al. Associations between night work and anxiety, depression, insomnia, sleepiness and fatigue in a sample of Norwegian nurses. PLoS one, 2013, 8.8: e70228.

[14] Basińska M., Wędzińska M.: Zmęczenie życiem codziennym a satysfakcja z życia rodziców dzieci z mózgowym porażeniem dziecięcym. 2014. 245-258.

[15] Chwojnicki K., Kozera G., Nyka W., Roszmann A., Skrzypek-Czerko M.: The influence of social support on the level of anxiety, depression and burden among stroke patients' caregivers - preliminary findings. Pielęgniarstwo Neurologiczne i Neurochirurgiczne 2013.

[16] Eldevik, M. Fagerbakke, et al. Insomnia, excessive sleepiness, excessive fatigue, anxiety, depression and shift work disorder in nurses having less than 11 hours in-between shifts. PloS one, 2013.

[17] Khamisa N., et al. Work-related stress, burnout, job satisfaction and general health of nurses. International journal of environmental research and public health, 2015, 12.1: 652666.

[18] Çelik S., et al. Fatigue in Intensive Care Nurses and Related Factors. The International Journal of Occupational and Environmental Medicine, 2017, 8.4 October: 1137-199-206.

[19] Dave D et al: Anxiety and Depression in caregivers of Intellectually Disabled Children. [20] Grabowska-Fudala B., Jaracz K.: Obciq̨żenie osób sprawujq̨cych opiekę nad chorymi po udarze mózgu - wyniki wstępne. W: Udar mózgu 2007, tom 9, nr 1.

[21] Imiela J., Kobos E.: Emotional state of the guardian responsible for a child with type 1 diabetes as a differential factor in family functions. Hygeia Public Health 2012. 
[22] Kołecki P., Maksymiuk T., Taborowska M., Wojnicz-Michera I., Zysnarska M.: Kobieta- opiekun osoby przewlekle chorej- wyznaczniki przeciqżenia. Nowiny Lekarskie 2010. 